\title{
Factors Predictive of Uterine Rupture after Operative Hysteroscopy
}

\author{
Z.Khallouk*, S.Bouhache, K.EL Moussaoui, F.Z.Louzali, S.Badsi, N.Zeraidi, A.Baidada \\ Gynecology obstetrics department .CHU IBN SINA, RABAT, Morocco
}

\begin{tabular}{ll}
\hline DOI: $10.36348 /$ sijog.2020.v03i12.001 & | Received: 14.10 .2020 | Accepted: 05.11 .2020 | Published: 05.12 .2020
\end{tabular}

*Corresponding author: Dr. Zaineb khallouk

\section{Abstract}

Objectives: To identify factors predictive of obstetric uterine rupture after operative hysteroscopy. When these factors are present, to know if there are means to prevent subsequent uterine rupture. Finally, to specify the criteria for extracting the fetus before rupture. Patients and methods: Description of a case of uterine rupture in a patient with a history of uterine septum rupture treated by operative hysteroscopy and retrospective analysis of the 12 similar observations reported in the literature. Results: Two types of situations are to be differentiated: uncomplicated hysteroscopic ablation of a polyp or submucosal myoma, which does not seem to modify the obstetrical prognosis; metroplasties for uterine malformation, resections of complex synechia, uterine perforations secondary to resection with the use of a monopole section current, constituting situations at high risk of obstetrical rupture. Conclusion: Uterine ruptures secondary to operative hysteroscopy are rare but serious. They may occur before any labour, and involve the vital prognosis of the motherfoetus. Once the risk factors have been identified, there is no way of preventing the progression to obstetric uterine rupture. The vigilance of the obstetrician in this context must be extreme, trying to authenticate the slightest clinical sign in favour of a pre-rupture of the uterus. However, systematic Caesarean section is not justified.

Keywords: Electrosection - Operative hysteroscopy - Metroplasty - Uterine rupture - Synechia.

Copyright (C) 2020 The Author(s): This is an open-access article distributed under the terms of the Creative Commons Attribution 4.0 International License (CC BY-NC 4.0) which permits unrestricted use, distribution, and reproduction in any medium for non-commercial use provided the original author and source are credited.

\section{INTRODUCTION}

Operative hysteroscopy has become the standard treatment for uterine septum rupture, synechia, endometrial polyps and submucosal myomas [1]. Shortterm operative morbidity appears to be minimal. The rate of operative complications (hemorrhage, infection, uterine perforation, hyponatremia, acute pulmonary edema) is $2.7 \%$ [2]; uterine perforation alone accounts for one third of operative complications [3]. However, the literature reports several documented cases of severe obstetrical complications such as uterine rupture related to a history of operative hysteroscopy [4-14]. Having had experience ourselves of obstetric uterine rupture after operative hysteroscopy, we believe that the obstetric prognosis following $\mathrm{HSCO}$ in certain circumstances should be reconsidered. We have tried to identify the factors predictive of the occurrence of such a complication and, if they should exist, to determine the means of preventing obstetric uterine rupture, and lastly to specify the criteria allowing us to extract the fetus before rupture.

\section{MATERIAL AND METHOD}

A consultation of the Medline database (keywords: complicated pregnancy, hysteroscopy) allowed us to find 12 cases of obstetrical complications related to operative hysteroscopy. With our own observation, we can draw up a list of 13 cases of documented uterine rupture following operative hysteroscopy, constituting the starting point of our study.

\section{RESULTS \\ Our observation}

Mrs. S. B 29, G3P1 with a history of two spontaneous abortions and whose etiological diagnosis was in favor of a partitioned uterus with the presence of a total partition. The patient underwent a hysteroscopic septal curettage 9 months prior to conception. The pregnancy was well monitored at term. The patient presented to the expectant room of the maternity ward 1 hour after the first uterine contractions had begun. 
On general examination: weight: $75 \mathrm{~kg}$, height: 1.66m, T*: 36, 8 c*, BP: 12/06 cmHg, Fc: 79 batt/min.

At the obstetrical examination: the uterine height is $29 \mathrm{~cm}$, regular positive $\mathrm{BCF}$, the vaginal touch found a supple median cervix erased at $80 \%$ dilated at 2 dgoites, mobile cephalic presentation, intact water pocket. Ultrasonography found a progressive monofetal pregnancy, positive cardiac activity, cephalic presentation, posterior placenta, amniotic fluid of normal quantity, BIP : $90 \mathrm{~mm}$ and LF: $69 \mathrm{~mm}$.

During the patient's monitoring in the expectant room she presented a medium to heavy bleeding with decelerations at the RCF, an emergency caesarean section was indicated for suspicion of uterine rupture. At the opening of the peritoneal cavity, the presence of medium-abundant hemoperitoneum was noted, segmental hysterotomy was performed which allowed the cephalic extraction of a live female newborn Abgar 8 -9-10. After the artificial delivery, exploration revealed the presence of a uterine rupture of $3-4 \mathrm{~cm}$ in diameter Seat at the uterine fundus midway between the two horns. A conservative treatment was decided for this patient with sutures on the 3 planes of the uterine prey (mucous, muscular and serous) for rupture, then simple hysterography of the lower segment. The patient remained under careful surveillance in the recovery room after transfusion of three red blood cells. The evolution was good, and the patient was discharged at D5 from the postoperative department.

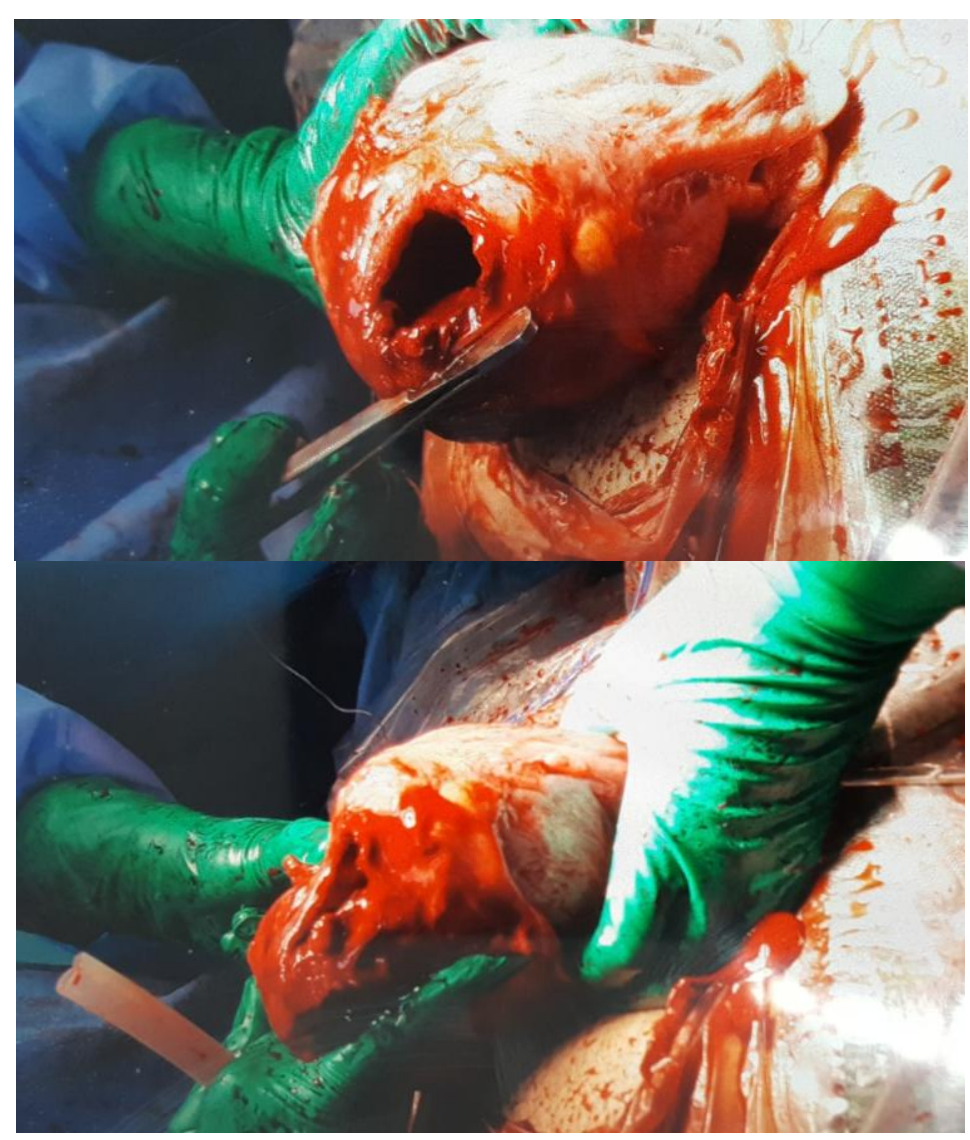

\section{The 12 cases of uterine rupture recorded to date}

Twelve cases of rupture of the pregnant uterus after operative hysteroscopy have been reported in the last 20 years [4-14]. These are uterine ruptures following 9 metroplasties for partitioned uterus, 2 synechia resections and 1 submucosal myoma resection. Their characteristics are detailed in Table I. Characteristics of uterine ruptures after operative hysteroscopy. 
Table-I: Characteristics of uterine ruptures after operative hysteroscopy

\begin{tabular}{|c|c|c|c|c|c|c|c|c|c|c|}
\hline & Indication & $\begin{array}{c}\text { Technique } \\
\text { of } \\
\text { resection }\end{array}$ & $\begin{array}{l}\text { Perforation } \\
\text { intraoperative }\end{array}$ & $\begin{array}{l}\text { Laparoscopy } \\
\text { of control }\end{array}$ & $\begin{array}{c}\text { HSG } \\
\text { of control }\end{array}$ & $\begin{array}{c}\text { Deadline } \\
\text { from } \\
\text { design }\end{array}$ & $\begin{array}{l}\text { Term } \\
\text { of the } \\
\text { rupture }\end{array}$ & $\begin{array}{c}\text { Rupture } \\
\text { during } \\
\text { the work }\end{array}$ & $\begin{array}{c}\text { Death } \\
\text { fetal }\end{array}$ & $\begin{array}{l}\text { Death } \\
\text { maternal }\end{array}$ \\
\hline $\begin{array}{l}\text { Creinin } \\
\text { of al. [11] }\end{array}$ & $\begin{array}{c}\text { Partition } \\
\text { uterine }\end{array}$ & $\begin{array}{l}\text { Diathermic } \\
\text { Cove } \\
\text { in } \\
\text { monopole }\end{array}$ & Yes & Yes & $\begin{array}{l}\text { Persistence } \\
\text { of a defect }\end{array}$ & $\begin{array}{c}\text { Not } \\
\text { communicated }\end{array}$ & $\begin{array}{c}\text { 38 SA } \\
\text { Caesarean } \\
\text { section } \\
\text { programmed }\end{array}$ & No & № & No \\
\hline $\begin{array}{l}\text { Halvorson } \\
\text { et al. [12] }\end{array}$ & $\begin{array}{l}\text { Partition } \\
\text { uterine }\end{array}$ & $\begin{array}{l}\text { Scissors } \\
\text { in cold } \\
\text { mode }\end{array}$ & Yes & Yes & NO & 1 month & $19 \mathrm{SA}$ & No & Yes & No \\
\hline Howe [6] & $\begin{array}{l}\text { Partition } \\
\text { uterine }\end{array}$ & $\begin{array}{l}\text { Scissors } \\
\text { in cold } \\
\text { mode }\end{array}$ & Yes & Yes & Normal & 1 year & $33 \mathrm{SA}$ & No & Yes & No \\
\hline $\begin{array}{l}\text { Lobaugh et } \\
\text { al [7]. }\end{array}$ & $\begin{array}{l}\text { Partition } \\
\text { uterine }\end{array}$ & Laser & No & Yes & $\begin{array}{l}\text { Remainder } \\
\text { of uterine } \\
\text { septum }\end{array}$ & years & $32 \mathrm{SA}$ & No & No & No \\
\hline $\begin{array}{l}\text { Yaron } \\
\text { et al. [9] }\end{array}$ & $\begin{array}{c}\text { Myoma } \\
\text { submucous }\end{array}$ & $\begin{array}{c}\text { Diathermic } \\
\text { Cove } \\
\text { in } \\
\text { monopole }\end{array}$ & Yes & No & NO & $\begin{array}{c}\text { Notion } \\
\text { of several } \\
\text { month }\end{array}$ & $33 \mathrm{SA}$ & No & No & No \\
\hline $\begin{array}{l}\text { Gurgan } \\
\text { ot al [13]. }\end{array}$ & Synechia & $\begin{array}{c}\text { Diathermic } \\
\text { Cove } \\
\text { in } \\
\text { monopole }\end{array}$ & Yes & No & Normal & 14 months & $36 \mathrm{SA}$ & № & № & No \\
\hline $\begin{array}{l}\text { Tannous } \\
\text { et al. [10] }\end{array}$ & $\begin{array}{c}\text { Partition } \\
\text { uterine }\end{array}$ & $\begin{array}{l}\text { Diathermic } \\
\text { Cove } \\
\text { in } \\
\text { monopole }\end{array}$ & No & Yes & NO & 2 months & $39 \mathrm{SA}$ & Yes & № & No \\
\hline $\begin{array}{l}\text { Tannous } \\
\text { et al. [10] }\end{array}$ & Synechia & $\begin{array}{l}\text { Diathermic } \\
\text { Cove } \\
\text { in } \\
\text { monopole }\end{array}$ & No & Yes & NO & 5 months & $41 \mathrm{SA}$ & Yes & № & No \\
\hline $\begin{array}{l}\text { Gabriele } \\
\text { et al [4]. }\end{array}$ & $\begin{array}{c}\text { Partition } \\
\text { uterine }\end{array}$ & $\begin{array}{l}\text { Scissors } \\
\text { in } \\
\text { monopole }\end{array}$ & Yes & No & NO & 11 months & $37 \mathrm{SA}$ & Yes & No & No \\
\hline $\begin{array}{c}\text { Chokri } \\
\text { et al. [18] }\end{array}$ & Synechia & $\begin{array}{c}\text { Diathermic } \\
\text { Cove } \\
\text { in } \\
\text { monopole }\end{array}$ & No & No & NO & 2 years & $35 \mathrm{SA}$ & No & Yes & No \\
\hline $\begin{array}{l}\text { Kerimis } \\
\text { et al. [8] }\end{array}$ & $\begin{array}{l}\text { Partition } \\
\text { uterine }\end{array}$ & $\begin{array}{l}\text { Scissors } \\
\text { in } \\
\text { monopole }\end{array}$ & No & Yes & NO & 3 months & $41 \mathrm{SA}$ & Yes & № & No \\
\hline $\begin{array}{l}\text { Angell } \\
\text { et al. [5] }\end{array}$ & $\begin{array}{l}\text { Partition } \\
\text { uterine }\end{array}$ & $\begin{array}{l}\text { Scissors } \\
\text { in cold } \\
\text { mode }\end{array}$ & No & Yes & $\begin{array}{c}\text { Remainder } \\
\text { partition } \\
\text { wall } \\
\text { uterine }\end{array}$ & $\begin{array}{c}\text { No } \\
\text { press release }\end{array}$ & 37 SA & № & No & No \\
\hline $\begin{array}{c}\text { Sentilhes } \\
\text { ot al. }\end{array}$ & $\begin{array}{l}\text { Retention } \\
\text { placental }\end{array}$ & $\begin{array}{c}\text { Diathermic } \\
\text { Cove } \\
\text { in } \\
\text { monopole }\end{array}$ & Yes & No & Normal & 5 years & $40 \mathrm{SA}$ & Yes & Yes & Ori \\
\hline
\end{tabular}

\section{DISCUSSION}

Risk factors for uterine rupture after operative hysteroscopy:

A Metroplasty for malformed uterus, particularly a partitioned uterus, is a known risk factor for obstetric uterine rupture [15]. 15] The few teams that still practiced this type of surgery by laparotomy in recent years underlined this fact [16]. The malformed uterus would be more fragile, although in the case of a septum it appears similar to the normal myometrium
[17]. The apparent simplicity of operative hysteroscopy does not absolve us from this type of complication. In fact, 9 obstetric uterine ruptures out of the 13 cases we report occurred in a context of metroplasty on a partitioned uterus. Uterine perforation during hysteroscopic metroplasties is certainly an aggravating factor in the risk of subsequent obstetric uterine rupture. Of the 9 uterine ruptures after metroplasty, 4 are interested in a perforation at the time of hysteroscopy. However, even in the absence of perforation detected 
by laparoscopy coupled with hysteroscopy, the possibility of rupture remains real; 4 of the patients in the series attest to this $[5,7,8,10]$. One can only wonder about the relevance of laparoscopy coupled with hysteroscopy to detect the perforation or its imminent risk.

Would not ultrasonography combined with hysteroscopy be more effective in assessing the thickness of the residual myometrium and its potential fragility [18]? This question remains unanswered for two reasons: none of the metroplaties in the series has been performed under ultrasound control, and no posthysteroscopic metroplasty obstetric uterine rupture performed under ultrasound control has been reported in the literature to date. Enlargement metroplasties in the context of Distilbene ${ }^{\circledR}$ uterus should theoretically expose to the same complications.

Considering the obstetrical risk after uterine septum resection and the existence of deliveries at term without obstetrical complications in the case of a septalated uterus, it is not justified, and may even be detrimental, to operate on asymptomatic uterine septum that has been discovered by chance $[19,20]$.

Severe uterine synechia, whether extensive or conjunctivo-muscular, reproduces a case close to uterine partitions; their resection, which can be likened to an enlargement metroplasty, constitutes a situation at risk of rupture in a future pregnant uterus. Two cases are identified in the series with or without associated perforation $[10,13]$.

Apart from our observation and that of Yaron et al. [9], hysteroscopic surgery of endometrial polyps, submucosal myomas and placental retentions does not appear to be at risk of obstetric uterine rupture. This is not mentioned in the literature. Our observation and that of Yaron et al. present the particularity of having complicated a perforation when using a single-polar section current. These two parameters considered independently do not generally have an impact on a future pregnant uterus. On the other hand, the combination of uterine perforation and monopolar section current clearly transforms the obstetrical prognosis of the uterus concerned. After the use of monopolar electric current, the tissue vitality of the underlying myometrium seems unknown. Deep electrical diffusion, which is difficult to control, may be responsible for extensive tissue necrosis.

Therefore, the healing power of the myometrium in case of perforation appears uncertain. A perforation in this context of using a monopole electrode is certainly no longer a simple perforation, but a high risk of subsequent uterine rupture.

\section{Can the risk of obstetric uterine rupture be prevented?}

Scissors used alone without power to cut the partitions or synechia do not protect against subsequent rupture [5]. The laser does not protect against this eventuality [7]. Uterine suturing of an identified perforation also does not prevent obstetric rupture [9]. However, cold mode resection and laser resection are preferable to single pole section current [2]. No obstetrical uterine rupture has been reported after the use of these 2 operating modes, without a previous uterine perforation, unlike the monopolar mode. In our observation, it would have been preferable to successfully complete the placental retention cure in cold mode without resorting to the monopolar mode: since the myometrium and endometrium remain fragile in the postpartum period, the use of single-polar section current should therefore be avoided or used only as a last resort during this period, given the major risk of iatrogeny (uterine perforation, synechia, weakening of the uterine wall).

The HSG is not recommended for assessing the strength of the uterus. Carried out 7 times out of 13, it was judged normal 6 times and did not prevent rupture. The control HSG, which objectifies a residual uterine septum, does not provide any additional safety [5]. Endovaginal ultrasonography is an excellent examination to evaluate the thickness of the uterine scar and to detect parietal defects in non-pregnant uteri [21]. However, the value of endovaginal ultrasound for remote monitoring of uterine perforation to identify patients at risk of rupture has not been demonstrated.

Some people recommend, although it is not consensual, waiting at least 6 months after uterine perforation by operative hysteroscopy before starting a pregnancy [10]. Analysis of our 13 observations shows that the time for perforation ruptures is highly variable, ranging from 2 months to 5 years. Lobaugh et al. describe the case of uterine rupture in a second pregnancy, when the patient had given birth normally for the first time after operative hysteroscopy [7]. A long delay after operative hysteroscopy at risk and normal conception or delivery following operative hysteroscopy is therefore no guarantee of subsequent obstetric safety.

Clearly, once the risk factors for uterine rupture have been identified, no precautions can be taken to avoid progression to obstetric uterine rupture.

\section{What would be the criteria for fetal extraction in an identified risk situation?}

In order to monitor residual myometrial thickness after operative hysteroscopy and to detect a risk situation, Howe performed a series of ultrasound scans throughout a pregnancy after septal section [6]. Ultrasound scans were normal until the abrupt onset of uterine rupture at $33 \mathrm{AS}$. Ultrasonography is therefore 
not a relevant examination during pregnancy to detect the imminence of rupture.

Caesarean section scheduled at 38 AS does not prevent uterine rupture before this term if there is a history of operative hysteroscopy. For 8 patients, rupture occurred before 38 AS. Systematic Caesarean section is therefore not justified because of the unexpected nature of the rupture, which most often occurs before the patient goes into labor.

The only elements of monitoring therefore remain the clinic and the study of the fetal heart rate. The classic signs of uterine pre-rupture in the context of a patient with a history of operative hysteroscopy should not be minimized at all.

It is essential to retrieve the report of the previous operative hysteroscopy; this must be included in the obstetrical record.

\section{CONCLUSION}

Uterine ruptures secondary to operative hysteroscopy are rare but serious, involving neonatal and maternal vital prognosis. The risk factors are clearly identified. They are metroplasties on malformed uterus, complex synechia lifts, and myometrial resections by single-polar section current complicated by perforation. Once these risk factors have been identified, nothing can prevent the evolution towards obstetrical uterine rupture.

The vigilance of the obstetrician in this context must be extreme, trying to authenticate the slightest clinical sign in favour of pre-rupture. However, systematic Caesarean section is not justified. The indications for operative hysteroscopy must be rigorous and concern only symptomatic patients, especially for young women who have a desire to become pregnant. New generation resectors using bipolar current may provide greater obstetrical safety after operative hysteroscopy.

\section{RÉFÉRENCES}

1. Grimbizis, G. F., Camus, M., Tarlatzis, B. C., Bontis, J. N., \& Devroey, P. (2001). Clinical implications of uterine malformations and hysteroscopic treatment results. Human reproduction update, 7(2), 161-174.

2. Propst, A. M., Liberman, R. F., Harlow, B. L., \& Ginsburg, E. S. (2000). Complications of hysteroscopic surgery: predicting patients at risk. Obstetrics \& Gynecology, 96(4), 517-520.

3. Peterson, H. B., Hulka, J. F., \& Phillips, J. M. (1990). American Association of Gynecologic Laparoscopists' 1988 membership survey on operative hysteroscopy. The Journal of reproductive medicine, $35(6), 590$.
4. Gabriele, A., Zanetta, G., Pasta, F., \& Colombo, M. (1999). Uterine rupture after hysteroscopic metroplasty and labor induction. A case report. The Journal of Reproductive Medicine, 44(7), 642-644.

5. Angell, N. F., Domingo, J. T., \& Siddiqi, N. (2002). Uterine rupture at term after uncomplicated hysteroscopic metroplasty. Obstetrics \& Gynecology, 100(5), 1098-1099.

6. Howe, R. S. (1993). Third-trimester uterine rupture following hysteroscopic uterine perforation. Obstetrics and gynecology, 81(5 (Pt 2)), 827-829.

7. Lobaugh, M. L., Bammel, B. M., Duke, D., \& Webster, B. W. (1994). Uterine rupture during pregnancy in a patient with a history of hysteroscopic metroplasty. Obstetrics and gynecology, 83(5 Pt 2), 838-840.

8. Kerimis, P., Zolti, M., Sinwany, G., Mashiach, S., \& Carp, H. (2002). Uterine rupture after hysteroscopic resection of uterine septum. Fertility and sterility, 77(3), 618-620.

9. Yaron, Y., Shenhav, M., Jaffa, A. J., Lessing, J. B., \& Peyser, M. R. (1994). Uterine rupture at 33 weeks' gestation subsequent to hysteroscopic uterine perforation. American journal of obstetrics and gynecology, 170(3), 786-787.

10. Tannous, W., Hamou, J., Henry-Suchet, J., Achard, B., \& Lelaidier, C. (1996). Ruptures utérines lors d'accouchements après hystéroscopie opératoire. La Presse médicale (1983), 25(4), 159161.

11. Creinin, M., \& Chen, M. (1992). Uterine defect in a twin pregnancy with a history of hysteroscopic fundal perforation. Obstetrics \& Gynecology, 79(5), 879-880.

12. Halvorson, L. M., Aserkoff, R. D., \& Oskowitz, S. P. (1993). Spontaneous uterine rupture after hysteroscopic metroplasty with uterine perforation. A case report. The Journal of reproductive medicine, 38(3), 236-238.

13. Gürgan, T., Yarali, H., Urman, B., Dagli, V., \& Dogan, L. (1996). Uterine rupture following hysteroscopic lysis of synechiae due to tuberculosis and uterine perforation. Human reproduction, 11(2), 291-293.

14. CHOKRI, A., CHEKIB, M., FETHI, Z., ANIS, F., \& SADOK, M. (2000). Rupture utérine au troisième trimestre après métroplastie hystéroscopique. Tunisie médicale, 78(8-9), 527 529.

15. Zabak K, Benifla JL, Uzan S. Septate uterus and reproduction disorders: current results of hysteroscopic septoplasty. Gynecol Obstet Fertil. 2001; 29: 829-40.

16. Ayhan, A., Yücel, I., Tuncer, Z. S., \& Kişnişçi, H. A. (1992). Reproductive performance after conventional metroplasty: an evaluation of 102 cases. Fertility and sterility, 57(6), 1194-1196.

17. Sparac, V., Kupesic, S., Ilijas, M., Zodan, T., \& Kurjak, A. (2001). Histologic architecture and 
vascularization of hysteroscopically excised intrauterine septa. The Journal of the American Association of Gynecologic Laparoscopists, 8(1), 111-116.

18. Letterie, G. S., \& Kramer, D. J. (1994). Intraoperative ultrasound guidance for intrauterine endoscopic surgery. Fertility and sterility, 62(3), 654-656.

19. Pellicer, A. (1997). Shall we operate on Müllerian defects? An introduction to the debate. Human reproduction (Oxford, England), 12(7), 1371-1372.
20. Doridot, V., Gervaise, A., Taylor, S., Frydman, R., \& Fernandez, H. (2003). Obstetric outcome after endoscopic transection of the uterine septum. The Journal of the American Association of Gynecologic Laparoscopists, 10(2), 271-275.

21. Armstrong, V., Hansen, W. F., Van Voorhis, B. J., \& Syrop, C. H. (2003). Detection of cesarean scars by transvaginal ultrasound. Obstetrics \& Gynecology, 101(1), 61-65. 